\title{
ROBERTO ALVIM
}

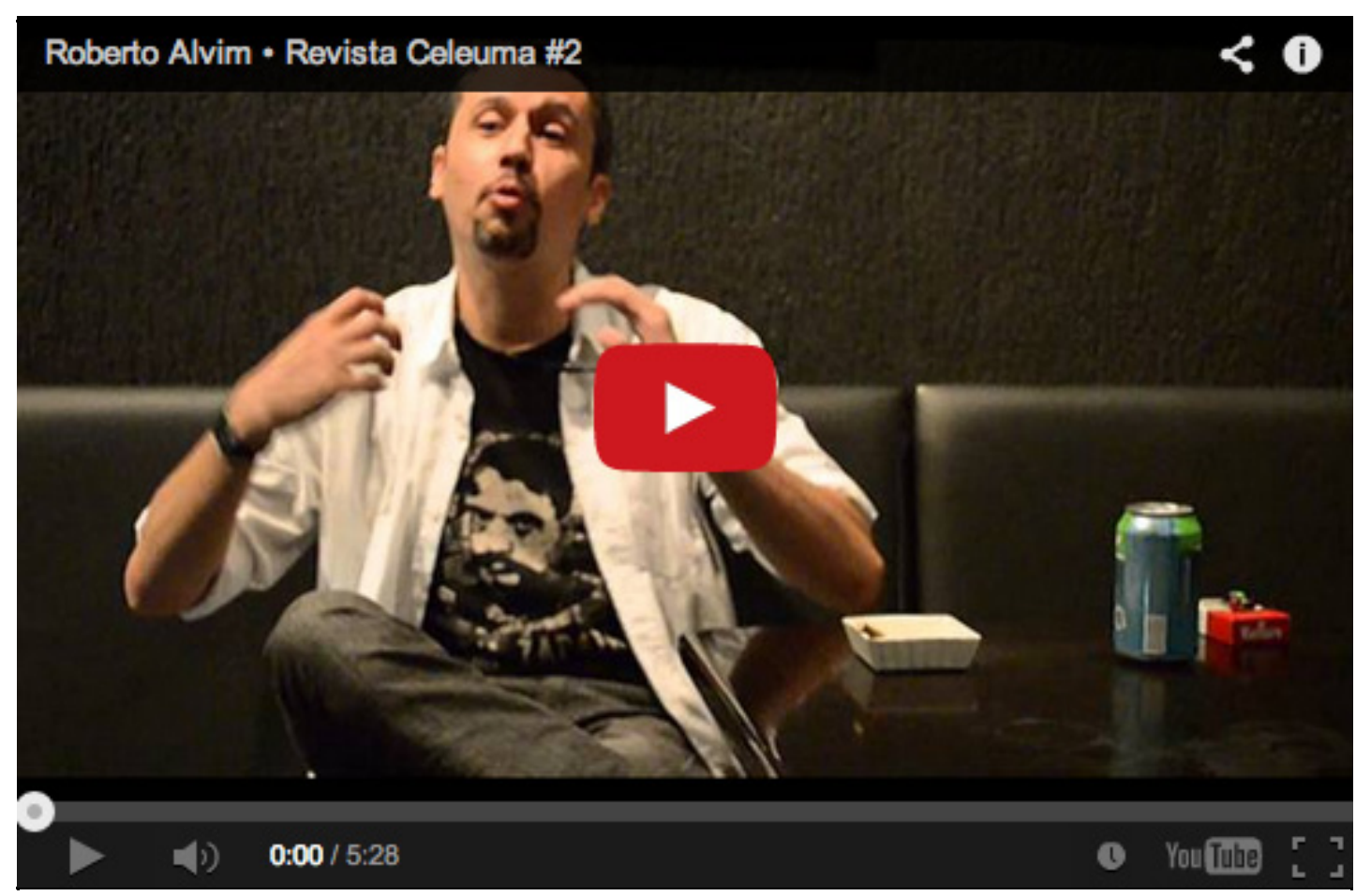

